\title{
A Cause of Protrusio Acetabuli: Hip Joint Synovial Chondromatosis
}

\author{
Protrüzyo Asetabulinin Nadir Bir Nedeni: Kalça Eklemi Sinoviyal Kondromatozisi
}

Fatih Bağcıer, Ayhan Kul, Hayri Oğul*

Atatürk University Faculty of Medicine, Department of Physical Medicine and Rehabilitation, Erzurum, Turkey

${ }^{*}$ Atatürk University Faculty of Medicine, Department of Radiology, Erzurum, Turkey

\section{To the Editor;}

A 60-year-old male patient presented to our clinic with pain, loss of range of motion in right hip and difficulty in walking. The pain started about 3 months previously and increased over time. Hip pain spreading to the trochanteric region of the right hip. The characteristic of the pain was mechanical. He did not feel pain while sleeping. Prolonged sitting or standing caused the hip to lock. Previously, he had received analgesic medications but there had been no significant improvement. There was no history of trauma. Physical examination revealed an antalgic gait and the motion of the right hip joint was limited and painful in all directions, whereas lumbar and left hip joint motions were unrestricted and painless. There were no neurological deficits of the lower extremities. Radiography of the pelvis indicated a narrowing joint space, and there were erosions on acetabular side of the joint and multiple soft tissue calcifications outside the joint capsule of the right knee. Magnetic resonance imaging of the right hip revealed findings consistent with synovial chondromatosis, which filled the joint space completely which was hypointense and acetabular protrusion progressing secondarily to synovial chondromatosis (Figure 1). Serological and biochemical markers and ultrasound of the inguinal region were normal. The patient was diagnosed with protrusio acetabuli in hip joint caused by synovial chondromatosis. Arthroscopic debridement were performed with symptomatic right hip.

The aim of presenting this case was to demonstrate that hip joint synovial chondromatosis which are not directly involved in etiological factors can cause secondary protrusio acetabuli. Protrusio acetabuli is identified with an acetabular line projecting ilioischial line for $3 \mathrm{~mm}$ in males and $6 \mathrm{~mm}$ in females on antero-posterior radiographs of the pelvis. The gradual deepening of the acetabular cavity is caused by primary idiopathic and secondary neoplastic, infectious, metabolic, inflammatory, traumatic, and genetic disorders
(1). This is the first case seen in the literature, despite various studies conducted about the etiology, no common factor was found. The joint replacement surgery is usually necessary in cases of severe pain or substantial joint restriction owing to secondary hip arthritis (2).

Keywords: Protrusio acetabuli, synovial chondromatosis, etiology, hip

Anahtar Kelimeler: Protrüzyo asetabuli, sinoviyal kondromatozis, etiyoloji, kalça

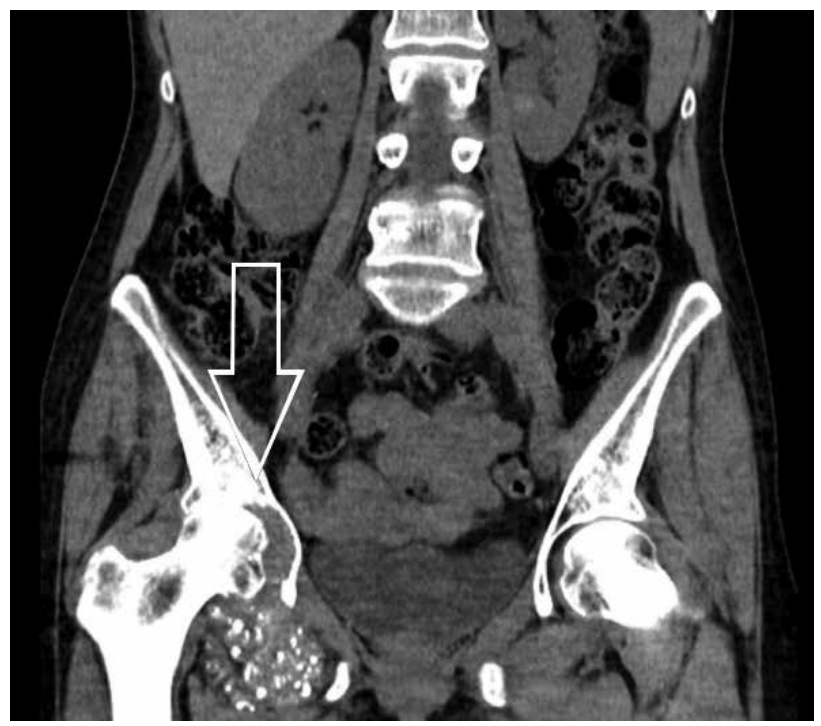

Figure 1. Magnetic resonance imaging of the right hip revealed findings consistent with synovial chondromatosis, which filled the joint space completely which was hypointense and acetabular protrusion progressing secondarily to synovial chondromatosis 


\section{Ethics}

Informed Consent: A consent form was completed by all participants.

Peer-review: Internally peer-reviewed.

\section{Authorship Contributions}

Surgical and Medical Practices: Fatih Bağcıer, Ayhan Kul, Hayri Oğul, Concept: Fatih Bağcıer, Ayhan Kul, Design: Fatih Bağcıer, Ayhan Kul, Data Collection or Processing: Fatih Bağcıer, Analysis or Interpretation: Fatih Bağcıer, Literature Search: Fatih Bağcıer, Writing: Fatih Bağcıer.
Conflict of Interest: No conflict of interest was declared by the authors.

Financial Disclosure: The authors declared that this study received no financial support.

\section{References}

1. Van De Velde S, Fillman R, Yandow S. The aetiology of protrusio acetabuli. Literature review from 1824 to 2006. Acta Orthop Belg 2006;72:524-9.

2. McBride MT, Muldoon MP, Santore RF, Trousdale RT, Wenger DR. Protrusio acetabuli: diagnosis and treatment. J Am Acad Orthop Surg 2001;9:79-88. 